\title{
Use of health care resources for varicella in the paediatric population, Jordan
}

Mohamed Abdullat, ${ }_{1}^{1}$ Wail Hayajneh, ${ }^{2}$ Ali Banni Issa, ${ }^{3}$ Abdullah Alshurman, ${ }^{4}$ Basma Marar, ${ }^{1}$ Ahmad Al-Hajajrah, ${ }^{1}$ Ahmad Al-Razim, ${ }^{5}$ Jenaya Rickard, ${ }^{6}$ Emmanouil Rampakakis, ${ }^{6}$ Alexandra Altland ${ }^{7}$ and Lara J. Wolfson ${ }^{7}$

${ }^{1}$ Ministry of Health, Al-Bashir Hospital, Amman, Jordan. ${ }^{2}$ Jordan University of Science and Technology, Irbid, Jordan. ${ }^{3}$ Pharmaceutical Research Center, King Abdullah University Hospital, Ar Ramtha, Jordan. ${ }^{4}$ Ministry of Health, Princess Rahma Teaching Hospital, Irbid, Jordan. ${ }^{5}$ Merck Sharp \& Dohme Idea Inc., Amman, Jordan. ${ }^{6}$ JSS Medical Research, Quebec, Canada. ${ }^{7}$ Merck \& Co., Inc., Kenilworth, New Jersey, United States of America. (Correspondence to: L. Wolfson: lara.wolfson@merck.com).

\author{
Abstract \\ Background: The exact burden of varicella is not well quantified in Jordan.
}

Aims: This study aimed to estimate the varicella burden in paediatric patients in Jordan who sought care in a hospital-based setting.

Methods: This was a multicentre, retrospective review of medical records of patients aged 0-14 years with a primary varicella diagnosis in Jordan between 2013 and 2018. The data assessed were: use of health care resources for varicella (outpatient and inpatient visits, tests and procedures, and medication use), and clinical complications of the infection. Estimated costs were based on health care resources used (direct costs) and lost revenue to the child's caregiver (indirect costs) for outpatients and inpatients.

Results: In total, 140 children with varicella were included: 78 outpatients, mean age (standard deviation) 4.4 (3.2) years, and 62 inpatients, mean age 4.0 (3.8) years. No outpatients had varicella-related complications, while 32 (52\%) inpatients had $\geq 1$ complication. The use of health care resources was higher for inpatients than outpatients, including prescription medication use $-94 \%$ of inpatients versus $6 \%$ of outpatients. Total costs of varicella were estimated at US\$ 66.1 ( $95 \%$ CI: 64.1-68.1) per outpatient and US\$ 914.7 (95\% CI: 455.6-1373.9) per inpatient.

Conclusions: Varicella is associated with considerable use of health care resources in Jordan and may be responsible for annual costs of US\$ 11.5 million. These results support universal varicella vaccination in Jordan.

Keywords: chicken pox, child, outpatients, inpatients, costs, Jordan

Citation: Abdullat M; Hayajneh W; Banni Issa A; Alshurman A; Marar B; Al-Hajajrah A: et al. Use of health care resources for varicella in the paediatric population, Jordan. East Mediterr Health J. 2021;27(2):159-166. https://doi.org/10.26719/2021.27.2.159

Received: 22/07/19; accepted: 27/01/20

Copyright (c) World Health Organization (WHO) 2021. Open Access. Some rights reserved. This work is available under the CC BY-NC-SA 3.0 IGO license (https://creativecommons.org/licenses/by-nc-sa/3.o/igo)

\section{Introduction}

Varicella is a highly contagious acute infectious disease caused by the varicella zoster virus that typically occurs in childhood. The annual incidence ranges from 2 to 16 cases per 1000 persons worldwide (1-3). The infection is characterized by mild symptoms, such as a pruritic vesicular rash, fever and malaise. Complications associated with varicella are known to occur and may include bacterial superinfections (skin, lungs or bones), cerebellar ataxia, encephalitis and aseptic meningitis (4).

In Jordan, no data exist on the incidence of varicella (5), however it has been estimated at 22 cases per 1000 persons (6). Treatment, rather than prevention, is the current approach to varicella infection in Jordan, where guidelines suggest that patients be provided with antipyretic and analgesic treatments and that they use disinfectant soap (7). Medical opinion in Jordan also discourages the use of antibiotics; however, an antiviral (acyclovir) is recommended in cases where immunodeficiency or severe eye and/or neurological complications are present (7).

As regards prevention, varicella vaccines have existed since the 1970s and mostly contain the live attenuated
Oka strain (Mav strain licensed in South Korea only). The Oka vaccine is available for administration as a 1-dose or 2-dose schedule; both schedules using Oka-strain vaccines are highly effective at preventing varicella. The vaccine is well tolerated, with minimal side-effects $(8-11)$. About 40 countries around the world have already included the varicella vaccine in their national immunization programmes (12). Many studies have demonstrated subsequent reductions in morbidity and mortality associated with varicella, as well as reductions in related use of health care resources (12).

The varicella vaccine is not currently included in Jordan's immunization programme, despite estimates that varicella infection likely represents a considerable health and economic burden that could be reduced through universal varicella vaccination (14-16). Jordanian health officials have spoken publicly about their planned tactic to combat communicable diseases in 2016-2020, including a strategy to introduce new vaccines to the national immunization programme (13).

Limited data exist on the epidemiology of varicella in Jordan, particularly data on the health burden and costs associated with varicella. The aim of this study was to 
provide evidence of the varicella burden in Jordan by assessing the complications of varicella and the use of health care resources and associated costs of the infection in paediatric patients in Jordan whose parents sought care for them in a hospital-based setting. These data can be used to quantify the overall economic burden of varicella in Jordan and evaluate the cost-effectiveness of varicella interventions, including the potential inclusion of varicella vaccination in the national immunization programme.

\section{Methods}

\section{Study design}

This study was a retrospective, observational review of medical records conducted from October 2017 to September 2018 in three public hospitals in Jordan (King Abdullah University Hospital in Al-Ramtha, Princess Rahma Pediatric Hospital in Irbid and Al-Basheer Hospital in Amman). We conducted the study in accordance with the Guidelines for Good Pharmacoepidemiology Practice. This study is part of an ongoing multicountry project that includes the following countries: Argentina (14), Mexico (15), Poland (16), Peru (17) and Hungary (18).

\section{Case selection}

WH, ABI, AA, BM, MA and AH screened patient medical records for varicella infection in the past 5 years (between 2013 and 2018), starting with the most recent year. We reviewed each medical record from the date of first primary varicella infection until resolution of the disease, or the last date of contact with the patient. Given the descriptive nature of the study, we selected a convenience sample of 150 patients, with an approximate 1:1 ratio of outpatients and inpatients to allow generalizability of the results to both population groups.

\section{Study population}

We included children aged 0-14 years, treated as inpatients and outpatients for a primary diagnosis of varicella. The outpatient group included patients who visited either the outpatient clinic or department of a hospital or the emergency department, and were not hospitalized for varicella. Inpatients were children who were either immediately or eventually, admitted to a hospital for their primary varicella infection. We excluded patients who had received the varicella vaccination before, or who presented with either a second case of varicella or herpes zoster infection.

\section{Outcome measures}

The varicella-related clinical complications that we evaluated included, but were not limited to: skin and soft tissue infection, meningitis, encephalitis, pneumonia, sepsis, cerebellitis, keratitis, febrile seizure, dehydration, neutropenia, thrombocytopenia, cellulitis and gastroenteritis.

We also assessed the use of health care resources for varicella treatment and related complications, which included: total number of outpatient visits (visits to the emergency room or hospital outpatient clinic); hospitalization and intensive care unit stay; use of non-prescription (over-the-counter) and prescription medications; tests and/or procedures performed; and allied health professional (e.g. dermatologist, ophthalmologist) consultations. Based on the health care resources used and lost revenue to the child's caregiver, we calculated direct and indirect costs per varicella case for both outpatients and inpatients. We then used these data to estimate the total annual cost related to varicella.

\section{Statistical analysis}

We included all eligible cases identified in the statistical analysis and did stratified analyses for outpatients and inpatients. We calculated the mean and standard deviation (SD) or $95 \%$ confidence interval (CI) for continuous variables, and frequencies for categorical variables.

We coded complications using the Medical Dictionary for Regulatory Activities (MedDRA) (19). To assess the varicella-related use of health care resources, we calculated the number and proportion of patients who used each health care resource, and the frequency or duration of use of the resource by the patient.

We determined the direct costs of varicella by multiplying the amount of resources (e.g. number of visits, days of hospitalization, days in the intensive care unit, number and duration of prescriptions) used per patient by the respective unit cost (20-23 and based on local expert opinion) of each resource in 2018 Jordanian dinars (JD), adjusting for inflation when necessary (24). We calculated the indirect costs as the lost revenue of the child's caregiver's using the national average monthly income (25) and the number of work days missed by the caregiver. We estimated the number of work days that the caregiver would have missed as the total number of days the patient was in hospital, including in the intensive care unit. For those treated as outpatients, we estimated 2.5 work days missed by the caregiver, as estimated in previous studies $(26,27)$. All costs are 2018 costs in JD.

By extrapolation, we calculated annual costs of varicella for children younger than 15 years based on the mean costs per varicella case identified in our study, the number of annual varicella cases in Jordan, the proportion of these cases attributed to patients younger than 15 years, and the proportion of these younger patients who were hospitalized. We based all extrapolated costs on 2018 costs in JD, which we also converted to United States dollars (US\$). The conversion rate at time of the analysis was JD 1 = US\$ 1.41 (28).

We used $S A S^{\circ}$ software version 9.4 for statistical analyses and SPSS, version 24 for the cost analysis.

\section{Ethical considerations}

In accordance with local regulations, we notified the local ethics committees for all participating sites. The following ethics committees approved the study: Institutional Review Board, Jordan University of Science and Technology, King Abdulla University Hospital, and the Institu- 
tional Committee for the Study of Scientific Research at the Prince Hamzah Hospital. The study did not require patient consent as we collected data retrospectively from medical records identified only by an encrypted patient number.

\section{Results}

Table 1 shows the characteristics of the patients and their varicella presentation according to their inpatient or outpatient status. We included 78 outpatients and 62 inpatients aged 0-14 years in the study, with a mean (SD) age of 4.4 (3.4) and 4.0 (3.8) years, respectively. Most of the patients were boys: $53 \%$ of the outpatients and $61 \%$ of the inpatients. The greatest proportion of outpatients and inpatients (40\% and $42 \%$, respectively) presented with 50-249 skin lesions during the rash. A greater proportion of inpatients $(14 \%)$ had $>500$ lesions during the rash than outpatients (5\%). Just over half of the inpatients

\begin{tabular}{|c|c|c|}
\hline \multicolumn{3}{|c|}{$\begin{array}{l}\text { Table } 1 \text { Patient and disease characteristics of children } \\
\text { diagnosed with varicella, Jordan }\end{array}$} \\
\hline Characteristic & $\begin{array}{l}\text { Outpatients } \\
\quad(n=78)\end{array}$ & $\begin{array}{l}\text { Inpatients } \\
(n=62)\end{array}$ \\
\hline \multicolumn{3}{|l|}{ Age (years) } \\
\hline Mean (SD) & $4.4(3.4)$ & $4.0(3.8)$ \\
\hline Range & $0.10-11.8$ & $0.03-12.9$ \\
\hline \multicolumn{3}{|l|}{ Sex, no. (\%) } \\
\hline Male & $41(53)$ & $38(61)$ \\
\hline Female & $37(47)$ & $24(39)$ \\
\hline \multicolumn{3}{|l|}{ Area of residence, no. (\%) } \\
\hline Urban & $65(83)$ & $55(89)$ \\
\hline Rural & $13(17)$ & $7(11)$ \\
\hline \multicolumn{3}{|l|}{ Body mass index $\left(\mathrm{kg} / \mathrm{m}^{2}\right)$} \\
\hline Mean (SD) & $16.9(1.7)$ & $16.4(3.0)$ \\
\hline \multicolumn{3}{|l|}{ Year of diagnosis, no. (\%) } \\
\hline 2013 & $5(6)$ & $16(26)$ \\
\hline 2014 & $6(8)$ & $13(21)$ \\
\hline 2015 & $16(20)$ & $10(16)$ \\
\hline 2016 & $12(15)$ & $15(24)$ \\
\hline 2017 & $39(50)$ & $3(5)$ \\
\hline 2018 & $0(0)$ & $5(8)$ \\
\hline \multicolumn{3}{|c|}{$\begin{array}{l}\text { Maximum number of skin lesions } \\
\text { during rash, no. (\%) }\end{array}$} \\
\hline$<50$ & $14(18)$ & $20(32)$ \\
\hline $50-249$ & $31(40)$ & $26(42)$ \\
\hline $250-500$ & $29(37)$ & $7(11)$ \\
\hline$>500$ & $4(5)$ & $9(14)$ \\
\hline $\begin{array}{l}\text { Patients with at least one } \\
\text { complication, no. }(\%)\end{array}$ & $O(0)$ & $32(52)$ \\
\hline \multicolumn{3}{|c|}{ Number of complications, no. $(\%)^{a}$} \\
\hline 1 & $O(0)$ & 29 (91) \\
\hline$>1$ & $\mathrm{o}(0)$ & $3(9)$ \\
\hline
\end{tabular}

SD: standard deviation.

aProportions based on the total number of complications $(n=32)$.
(52\%; 32/62) had one or more complication, among whom $9 \%$ (9/62) had two or more complications; no outpatients had complications. None of the patients was considered immunocompromised.

The most common complications in inpatients were: skin and soft tissue infection (24.1\% of complications), pneumonia (20.7\%), encephalitis $(13.8 \%)$, sepsis $(13.8 \%)$ and cerebellitis (10.3\%); $17.2 \%$ were other types of complication, including neutropenia, thrombocytopenia, keratitis, cellulitis and gastroenteritis.

The use of health care resources associated with varicella is summarized by patient status in Table 2 . For outpatients, $81 \%$ visited an emergency room while only $19 \%$ went to the hospital outpatient clinic. The mean number of visits per patient to both the emergency room and outpatient clinic was 1.o. For inpatients, 31\% and $8 \%$ visited the emergency department or hospital outpatient clinic, respectively, before being admitted to hospital, both with a mean number of visits of 1.0 per patient. The mean $(95 \% \mathrm{CI})$ length of stay in hospital was 5.6 (95\% CI: 4.3-6.9) days. In addition, $2 \%$ of inpatients were admitted to the intensive care unit, with an average duration of stay of 2 days. The use of over-the-counter medication was high in both outpatients ( $96 \%$ of outpatients) and inpatients (60\%); the mean number of medicines used per patient was 2.3 (95\% CI: $2.2-2.5$ ) for outpatients and 2.1 (95\% CI: 1.8-2.4) for inpatients. The use of prescription medication was higher in inpatients than outpatients (94\% of inpatients versus $6 \%$ of outpatients); the mean number of prescription medications per patient was 2.2 for inpatients and 1.0 for outpatients. About two thirds of inpatients (68\%) underwent tests and procedures and 18\% had consultations with allied health professionals. The mean number of tests per inpatient was 5.0 (95\% CI: 4.25.9) and the mean number of consultations with allied health professionals was 1.4 (95\% CI: 1.0-1.7).

Antibiotics were prescribed for $69 \%$ of inpatients (Table 3); no outpatients were prescribed antibiotics. The mean number of antibiotics prescribed per inpatient was 1.7 (95\% CI: 1.4-1.9), with a mean duration of 8.5 (95\% CI: 7.1-9.9) days. The most commonly prescribed antibiotics were ceftriaxone (40\%), piperacillin-tazobactam (13\%), ampicillin (10\%) and vancomycin (10\%). The mean duration of use was 5.3 (95\% CI: 4.2-6.4) days for ceftriaxone, 6.6 (95\% CI: 6.0-7.2) for piperacillin-tazobactam, 3.0 (95\% CI: 2.3-3.7) for ampicillin and 6.8 (95\% CI: 5.2-8.5) days for vancomycin.

Table 4 presents the key unit costs that were used to calculate the varicella-associated costs of each resource used per patient. These cost per patients are shown in Table 5 for inpatients and outpatients. The mean overall total direct cost per outpatient was 9.7 (95\% CI: 8.2-11.1) JD. The mean cost of emergency department visits was 6.0 (95\% CI: 5.3-6.7) JD, which accounted for most of the overall total direct cost for outpatients. Visits to a hospital outpatient clinic (mean cost 1.6 (95\% CI: 0.9-2.4) JD) and over-the-counter treatment (mean cost 1.8 (95\% CI: 0.43.2) JD) also contributed to the total direct outpatient cost. For inpatients, the mean overall total direct cost was 565.5 


\begin{tabular}{|c|c|c|c|c|}
\hline \multirow{2}{*}{ Type of health care resource utilization } & \multicolumn{2}{|c|}{ Outpatients $(n=78)$} & \multicolumn{2}{|c|}{ Inpatients $(n=62)$} \\
\hline & $\%$ patients & Mean $(95 \% \mathrm{CI})^{\mathrm{a}}$ & $\%$ patients & Mean $(95 \% \text { CI })^{\mathrm{a}}$ \\
\hline Visit to an emergency room & 81 & $1.0(1.0-1.1)$ & 31 & 1.0 (NA) \\
\hline Visit to hospital outpatient clinic & 19 & 1.0 (NA) & 8 & 1.0 (NA) \\
\hline Hospital stay & NA & NA & 100 & $5.6(4.3-6.9)$ \\
\hline Intensive care unit stay & NA & NA & 2 & $2.0(\mathrm{NA})$ \\
\hline Prescription medications & 6 & 1.0 (NA) & 94 & $2.2(2.0-2.5)$ \\
\hline Over-the-counter medications & 96 & $2.3(2.2-2.5)$ & 60 & $2.1(1.8-2.4)$ \\
\hline Tests and procedures performed & 3 & 1.0 (NA) & 66 & $5.0(4.2-5.9)$ \\
\hline Consultation of allied health professionals & 0 & NA & 18 & $1.4(1.0-1.7)$ \\
\hline
\end{tabular}

CI: confidence interval; NA: not applicable;

${ }^{a}$ Average number of health care resources used per patient. For inpatient hospital and intensive care unit stay, average length of stay in days.

(95\% CI: 242.8-888.3) JD. Hospital stay (mean cost 270.1 (95\% CI: 207.8-332.4) JD) and prescription medications (mean cost 240.2 (95\% CI: 0.0-559.5) JD) accounted for most of the total direct cost for inpatients. Tests and procedures also made up a considerable portion of the total direct inpatient costs (mean cost 46.3 (95\% CI: $28.1-$ 64.5) JD). The mean indirect cost per outpatient was 37.2 JD and while this cost per inpatient was 83.0 (63.8-102.1). Thus the overall costs per patient for outpatients and inpatients were 46.8 (95\% CI: 45.4-48.3) JD (US\$ 66.1 (95\% CI: 64.1-68.1)) and 648.5 (95\% CI: 323.0-974.1) JD (US 914.7 (95\% CI: 455.6-1373.9)), respectively.

The estimated annual direct and indirect costs associated with varicella among the paediatric population $(<15$ years old) in Jordan are shown in Table 6. We derived these estimates from the cost per varicella case in Table 5, the estimated number of varicella cases a year in Jordan (172 000 cases) (6), the proportion attributed to patients younger than 15 years of age $(83.5 \%, n=143620)$ and the hospitalization rate $(1.62 \%)$ reported for other Middle Eastern countries $(29,30)$. The total estimated annual direct and indirect costs of varicella infection in Jordan for 2018, based on 141295 outpatients and 2325 inpatients, were 2685445.1 JD (US\$ 3787651.8 ) and 5446286.1 JD (US\$ 7681644.7$)$, respectively, giving an overall total annual cost of 8131 731.2 JD (US\$ 11469 296.5). Expressing this as the cost per child who would be eligible for varicella vaccination in 2018 , this equates to a cost of US\$ 47.2 per child.

\section{Discussion}

We retrospectively assessed the health-related burden associated with varicella infection in Jordan among the paediatric population who sought care in a hospital-based setting. Our results emphasize both the clinical and health care burden of varicella in paediatric patients seen as either outpatients or inpatients.

In inpatients, $52 \%$ had at least one of the more common complications of varicella - skin and soft tissue infection, pneumonia, encephalitis, sepsis and cerebellitis - which is similar to the findings of other studies $(29,30)$. The average duration of hospitalization in our study (5.6 days) was also comparable to the length of stay identified in other countries $(30,31)$, which ranged from 3 to 8 days. Our results are in line with the rates of varicella-associated complications identified in paediatric inpatients in other Middle Eastern countries (29,30).

About $70 \%$ of inpatients in our study were prescribed at least one antibiotic (mean number $=1.7$ prescriptions). It is possible, however, that many outpatients were also treated with antibiotics, which our study could not identify, as there is an established trend in Jordan for pharmacists to dispense antibiotics without a prescription

\begin{tabular}{|c|c|}
\hline Variable & Value $(n=62)$ \\
\hline Patients prescribed $\geq 1$ antibiotic, no. (\%) & $43(69)$ \\
\hline $\begin{array}{l}\text { Number of antibiotics prescribed per patient }{ }^{a} \text {, } \\
\text { mean }(95 \% \mathrm{CI})\end{array}$ & $1.7(1.4-1.9)$ \\
\hline $\begin{array}{l}\text { Duration of antibiotics prescribed per patient } \\
\text { days, mean }(95 \% \mathrm{CI})\end{array}$ & $8.5(7.1-9.9)$ \\
\hline \multicolumn{2}{|l|}{ Antibiotics prescribed, no. (\%) } \\
\hline Ceftriaxone & $25(40)$ \\
\hline Piperacillin-tazobactam & $8(13)$ \\
\hline Ampicillin & $6(10)$ \\
\hline Vancomycin & $6(10)$ \\
\hline Azithromycin & $3(5)$ \\
\hline Penicillin & $2(3)$ \\
\hline Other $^{b}$ & $14(23)$ \\
\hline \multicolumn{2}{|l|}{ Duration of antibiotic use ${ }^{a}$, days, Mean (95\% CI) } \\
\hline Ceftriaxone & $5.3(4.2-6.4)$ \\
\hline Piperacillin-tazobactam & $6.6(6.0-7.2)$ \\
\hline Ampicillin & $3.0(2.3-3.7)$ \\
\hline Vancomycin & $6.8(5.2-8.5)$ \\
\hline Azithromycin & $4.3(1.5-7.2)$ \\
\hline Penicillin & $1.0(\mathrm{NA})$ \\
\hline Other ${ }^{b}$ & $6.2(4.0-8.4)$ \\
\hline
\end{tabular}

CI: confidence interval; NA: not available.

${ }^{a}$ For inpatients prescribed at least 1 antibiotic.

'Other antibiotics included: cefazolin, cefixime, cefotaxime, cefuroxime, chloramphenicol, fusidic acid, furosemide, gentamicin, nystatin, oxacillin, sulfamethoxazole-trimethoprim and teicoplanin. 


\begin{tabular}{l}
\hline $\begin{array}{l}\text { Table } 4 \text { Unit costs of health care resources for varicella, } \\
\text { Jordan }\end{array}$ \\
\begin{tabular}{lc} 
Health care resource & Mean cost, JD (US\$) \\
\hline Visit to the emergency room $^{\mathrm{a}}$ & $7.1(10.1)$ \\
Visit to hospital outpatient clinic & $8.5(12.0)$ \\
Hospital stay & $48.4(68.3)$ \\
Intensive care unit stay $^{\mathrm{b}}$ & $90.3(127.4)$ \\
\hline
\end{tabular}
\end{tabular}

JD: Jordanian Dinar; USș: United States dollar

${ }^{a}$ Cost per visit.

${ }^{b}$ Cost per days of stay.

$(32,33)$. The lack of stewardship of the dispensing of antibiotics may contribute to antimicrobial resistance, as it can result in over-prescription of antibiotics or in patients not completing the full course of antibiotics, among others. Jordan recently began developing a national antimicrobial resistance surveillance system in collaboration with the World Health Organization (WHO) to combat antimicrobial resistance. As policy-makers in Jordan work on strategies to address antimicrobial resistance, universal varicella vaccination should be considered as a possible supportive tactic that could indirectly reduce the use of antimicrobials often required for bacterial complications of varicella infection.

With respect to the costs associated with varicella, we showed that varicella in outpatients had a direct mean cost of 9.7 JD per patient, whereas the mean cost for inpatients was 565.6 JD per patient. One of the reasons for the low cost in outpatients could be due to the hospital-based setting of our study. As a result, follow-up of outpatients was probably lacking and so we may not have fully captured all the use of health care resources associated with this group of patients. The indirect costs of varicella differed slightly between groups: 37.2 JD per outpatient and 83.0 JD per inpatient.

In our extrapolated cost analysis, we estimated that the total annual direct cost associated with varicella for 2018 in Jordan was US\$3787651.8. According to WHO, Jordan has a per-capita health expenditure of 798 international dollars (34), which equates to a total annual health expenditure of about US\$ 507 million in 2014. Therefore, at the very least, $0.7 \%$ of the annual health expenditure in Jordan is a direct result of varicella infection. We estimated the total annual indirect cost of varicella for 2018 as US\$ 7681644.7 , for an overall total (direct + indirect) cost of US\$ 11469296.5 . This is a substantial cost burden for a lower middle-income country which could be potentially offset by universal varicella vaccination. Health economic models have already demonstrated that the implementation of either a 1-dose or 2-dose universal varicella vaccination in Jordan would significantly reduce the cost burden associated with treatment, specifically a cost saving of US\$ 83.40 per person (6).

The limitations of this study include the retrospective chart review design, in that only information recorded on patient charts was captured, which may have led to an underestimation of the associated use of health care resources for varicella and the resultant costs. The hospital-based setting also likely resulted in an underestimation of the use of health care resources and costs in outpatients specifically as many would not have had follow-up visits that allowed every resource used to be properly captured. Furthermore, indirect costs were based only on the cost of lost work for the child's caregiver and not on out-of-pocket patient expenses, which again may have led to an underestimation of indirect costs. The small sample size in our study and limited participating

\begin{tabular}{|c|c|c|}
\hline \multirow[t]{2}{*}{ Costs } & Outpatients $(n=78)$ & Inpatients $(n=62)$ \\
\hline & Mean cost, JD (95\% CI) & Mean cost, JD ( $95 \% \mathrm{CI})$ \\
\hline \multicolumn{3}{|l|}{ Direct costs } \\
\hline Visit to emergency room & $6.0(5.3-6.7)$ & $2.2(1.4-3.0)$ \\
\hline Visit to hospital outpatient clinic & $1.6(0.9-2.4)$ & $0.6(0.0-1.1)$ \\
\hline Hospital stay & NA & $270.1(207.8-332.4)$ \\
\hline Intensive care unit stay & NA & $2.9(0.0-8.7)$ \\
\hline Prescription medications & $0.2(0.0-0.4)$ & $240.2^{\mathrm{a}}(0.0-559.5)$ \\
\hline Over-the-counter treatments & $1.8(0.4-3.2)$ & $0.7(0.3-1.0)$ \\
\hline Tests and/or procedures & $0.2(0.0-0.8)$ & $46.3(28.1-64.5)$ \\
\hline Allied health professional consultations & 0.0 & $5.6(2.2-8.9)$ \\
\hline Direct costs (subtotal) & $9.7(8.2-11.1)$ & $565.5^{\mathrm{a}}(242.8-888.3)$ \\
\hline \multicolumn{3}{|l|}{ Indirect costs } \\
\hline Absence of child's caregiver from work ${ }^{\mathrm{b}}$ & $37.2(\mathrm{NA})$ & $83.0(63.8-102.1)$ \\
\hline Total costs & $46.8(45.4-48.3)$ & $648.5^{a}(323.0-974.1)$ \\
\hline \multicolumn{3}{|c|}{ 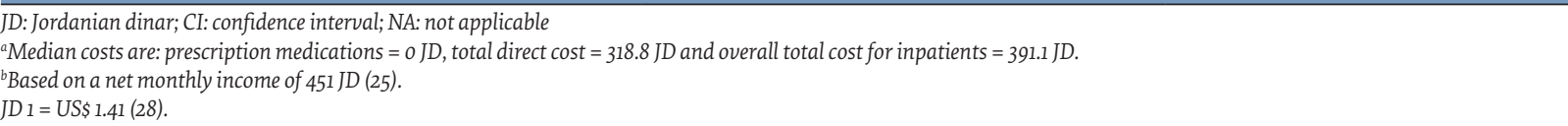 } \\
\hline
\end{tabular}


Table 6 Estimated annual costs of varicella in paediatric patients, Jordan

\section{Item}

\section{Direct costs}

$\begin{array}{lcc}\text { Outpatient visit to emergency room } & 847209.2(1194935.4) & 31.5 \\ \text { Visit to hospital outpatient clinic } & 231589.4(326642.3) & 8.6 \\ \text { Hospital stay } & 628038.6(885809.1) & 23.4 \\ \text { Intensive care unit stay } & 6766.4(9543.5) & 0.3 \\ \text { Prescription medications } & 583948.0(823622.0) & 21.7 \\ \text { Over-the-counter treatments } & 254429.1(358856.2) & 9.5 \\ \text { Tests and/or procedures } & 120327.1(169713.9) & 4.5 \\ \text { Allied health professional consultations } & 13137.4(18529.5) & 0.5 \\ \text { Direct costs (subtotal) } & 2685445.1(3787651.8) & \text { NA } \\ \text { Indirect costs } & & \\ \text { Absence of child's caregiver from work } & 5446286.1(7681644.7) & \text { NA }\end{array}$

JD: Jordan dinars; US\$: United States dollars; NA: not applicable.

These estimates are based on 172000 cases a year (29) in Jordan and the proportion attributed to patients younger than 15 years of age $(83.5 \%, n=143620)$. The proportions of outpatients $(n=141295)$ and inpatients $(n=2325)$ are based on the hospitalization rate $(1.62 \%)$ reported for other Middle Eastern countries $(30,31)$.

sites may have reduced the external validity and hence generalizability of our findings.

The estimated annual costs associated with varicella may also be biased since our study only captured outpatients who had hospital-based care and not children with varicella who may have received care outside of hospital. Furthermore, the annual number of varicella cases used in our national cost estimates may have been overestimated because, as a result of limited information on varicella epidemiology in Jordan, it was based on the number generated from a health economic model. We also assumed that due to high health care coverage in Jordan (23), all outpatients with varicella would seek care, which may have overestimated the annual cost burden.

Despite these limitations, this is the first study to report on the use of health care resources for varicella in Jordan and the associated costs. Our results illustrate both the substantial amount of health resources used to manage varicella, including high antibiotic use, and the economic burden that results from the infection.

In conclusion, varicella is associated with considerable burden to the health care system in Jordan. These results support the need for a universal varicella vaccination as a way to both reduce the varicella-related burden and limit the use of antimicrobials in Jordan.

Funding: AR, AAltland and LJW are employees of Merck Sharp \& Dohme Corp., a subsidiary of Merck \& Co., Inc., Kenilworth, USA, who may own stock and/or hold stock options in the company. ABI, AAlshurman, BM and $\mathrm{AH}$ received research support from Merck Sharp \& Dohme Corp. MA, WH, JR (employee of JSS Medical Research) and ER (employee of JSS Medical Research) served as paid scientific consultants to Merck Sharp \& Dohme Corp. WH also serves as the chairman for the National Immunization Technical Advisory Group of Jordan.

Competing interests: None declared.

\section{Utilisation des ressources de soins de santé pour la varicelle dans la population pédiatrique, Jordanie \\ Résumé}

Contexte : La charge exacte de varicelle n'est pas bien quantifiée en Jordanie.

Objectifs : La présente étude visait à estimer la charge de varicelle chez des patients pédiatriques en Jordanie qui ont été soignés dans un établissement hospitalier.

Méthodes : Il s'agissait d'une analyse multicentrique rétrospective des dossiers médicaux de patients âgés de 0 à 14 ans ayant reçu un diagnostic primaire de varicelle en Jordanie entre 2013 et 2018. Les données évaluées étaient les suivantes : utilisation des ressources de soins de santé pour la varicelle (consultations externes et hospitalières, tests et procédures, et prise de médicaments) et complications cliniques de l'infection. Les coûts estimés étaient basés sur les ressources de soins de santé utilisées (coûts directs) et les pertes de revenus pour la personne s'occupant de l'enfant (coûts indirects) pour les patients externes et hospitalisés.

Résultats : Au total, 140 enfants atteints de varicelle ont été inclus : 78 patients externes, âge moyen (écart type) 4,4 ans (3,2), et 62 patients hospitalisés, âge moyen 4,0 ans (3,8). Aucun patient externe ne présentait de complications 
liées à la varicelle, tandis que 32 patients hospitalisés (52\%) présentaient une complication ou plus. Le recours aux ressources de soins de santé était plus élevé chez les patients hospitalisés que chez les patients externes, y compris les médicaments sur ordonnance : $94 \%$ des patients hospitalisés contre $6 \%$ des patients externes. Le coût total du traitement de la varicelle a été estimé à 66,1 dollars US (IC à $95 \%: 64,1-68,1$ ) par patient externe et 914,7 dollars US (IC à $95 \%$ : 455,6-1373,9) par patient hospitalisé.

Conclusions : La varicelle est associée à une utilisation considérable des ressources de soins de santé en Jordanie et peut être responsable de coûts annuels s'élevant à USD 11,5 millions. Ces résultats plaident en faveur de la vaccination universelle contre la varicelle en Jordanie.

$$
\begin{aligned}
& \text { استخدام موارد الرعاية الصحية لعلاج جديري الماء في صفوف السكان من الأطفال، الأردن } \\
& \text { محمد عبد الله، وائل حياجنة، علي عيسى، عبد الله الشرمان، بسمة مرار، أحمد الحجاجرة، أحمد الرئه الريم، جينيا ريكارد، إيهانويل رامباكاكيس، } \\
& \text { ألكسندرا ألتلاند، لارا ولفسون }
\end{aligned}
$$

$$
\text { الخلفية: لم يتحدَّد العبء الدقيق من جديري الماء بشكل كمّي مناسب في الأردن. }
$$

$$
\text { الأهداف: هدفت هذه الدراسة إلى تقدير عبء جديري الماء في صفوف المرضى من من الأطفال الذين التمسو الرئ الرعاية في المستشفيات بالأردن. }
$$

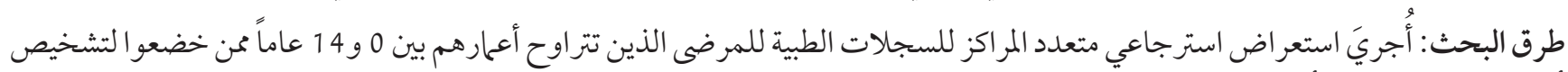

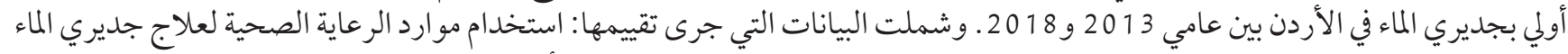

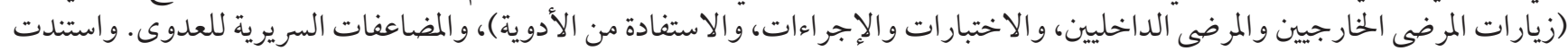

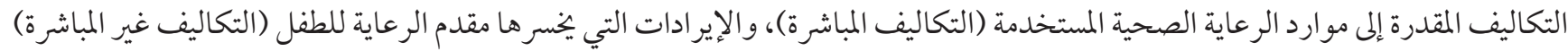

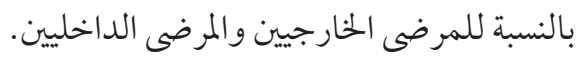

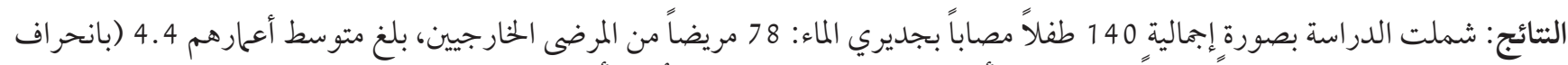

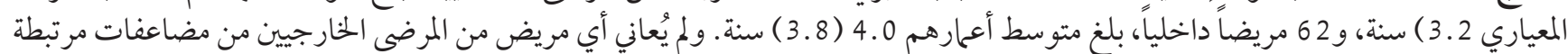

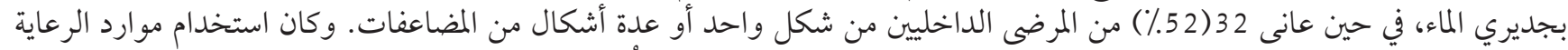

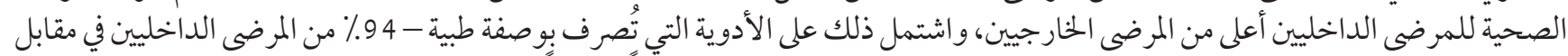

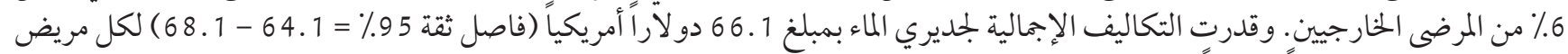

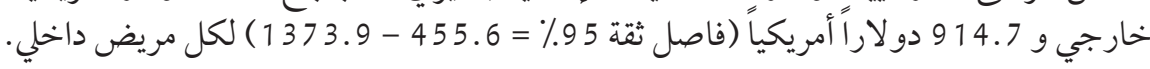

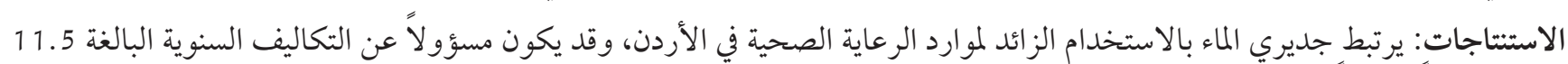

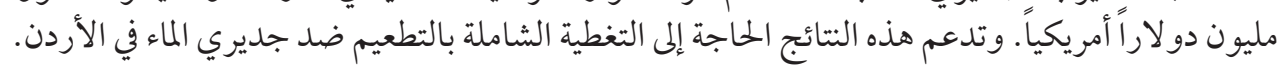

\section{References}

1. Bardach A, Cafferata ML, Klein K, Cormick G, Gibbons L, Ruvinsky S. Incidence and use of resources for chickenpox and herpes zoster in Latin America and the Caribbean - a systematic review and meta-analysis. Pediatr Infect Dis J. 2012;31(12):1263-8. http://doi.org/10.1097/INF.obo13e31826ff3a5

2. Heininger U, Seward JF. Varicella. Lancet. 2006;368(9544):1365-76. http://doi.org/10.1016/So140-6736(06)69561-5

3. Sadzot-Delvaux C, Rentier B, Wutzler P, Asano Y, Suga S, Yoshikawa T, et al. Varicella vaccination in Japan, South Korea, and Europe. J Infect Dis. 2008;197(Suppl 2):S185-90. https://doi.org/10.1086/522163

4. Gershon AA. Varicella-zoster virus infections. Pediatr Rev. 2008;29(1):5-10; quiz 1. https://doi.org/10.1542/pir.29-1-5

5. Al-Turab M, Chehadeh W. Varicella infection in the Middle East: prevalence, complications, and vaccination. J Res Med Sci. 2018;23:19. https://doi.org/10.4103/jrms.jrms_979_17

6. Hayajneh W, Al Abdullat M, Al Shurman A, Maalouf J, Kuter B, Weiss T, et al. Estimating the health and economic impact of universal varicella vaccination in Jordan. Open Forum Infect Dis. 2017;4(Suppl 1):S39-10. https://dx.doi.org/10.1093\%2Fofid\%2Fofx163.721

7. [Chickenpox in children.] [Internet]. Jordanian Medical Pages; 2020 (http://jomedicalpages.com/health.php?section=1\&num=548, accessed 9 June 2020). [In Arabic].

8. Marin M, Marti M, Kambhampati A, Jeram SM, Seward JF. Global varicella vaccine effectiveness: a meta-analysis. Pediatrics. 2016;137(3):e20153741. https://doi.org/10.1542/peds.2015-3741

9. Yin $\mathrm{M}, \mathrm{Xu} \mathrm{X}$, Liang Y, Ni J. Effectiveness, immunogenicity and safety of one vs. two-dose varicella vaccination: a meta-analysis. Expert Rev Vaccines. 2018;17(4):351-62. https://doi.org/10.1080/14760584.2018.1433999 
10. Zhu S, Zeng F, Xia L, He H, Zhang J. Incidence rate of breakthrough varicella observed in healthy children after 1 or 2 doses of varicella vaccine: results from a meta-analysis. Am J Infect Control. 2018;46(1):e1-e7. https://doi.org/10.1016/j.ajic.2017.07.029

11. Cheng HY, Chang LY, Lu CY, Huang LM. Epidemiology of breakthrough varicella after the implementation of a universal varicella vaccination program in Taiwan, 2004-2014. Sci Rep. 2018;8(1):17192. https://doi.org/10.1038/s41598-018-35451-y

12. Varela FH, Pinto LA, Scotta MC. Global impact of varicella vaccination programs. Hum Vaccin Immunother. 2019;15(3):645-57. ht tps://10.1080/21645515.2018.1546525

13. The National Strategy for Health Sector in Jordan 2016-2020. Amman: Hashemite Kingdom of Jordan High Health Council; 2016 (http://www.nationalplanningcycles.org/sites/default/files/planning_cycle_repository/jordan/national_strategy_for_health_sector_2016-2020_jordan.pdf, accessed 21 December 2018).

14. Giglio N, Monsanto H, Rampakakis E, Yang HK, Kuter BJ, Wolfson LJ. Economic burden of varicella in children 1-12 years of age in Argentina, 2009-2014. J Med Econ. 2018;21(4):416-24. https://doi.org/10.1080/13696998.2018.1431919

15. Vázquez Rivera M, Bolde Villarreal C, Monsanto H, Rampakakis E, Altland A, Wolfson L. Estudio retrospectivo que evalúa la carga de la varicela en México en menores de 1-14 años tratados en 10 sitios. Acta Pediátrica de México [Retrospective study evaluating the burden of chickenpox in Mexico in children aged 1-14 years treated in 10 sites]. 2018;39(6):334-48. http://dx.doi. org/10.18233/APM39No6pp334-3481731

16. Wysocki J, Malecka I, Stryczynska-Kazubska J, Rampakakis E, Kuter B, Wolfson LJ. Varicella in Poland: economic burden in children 1-12 years of age in Poland, 2010-2015. BMC Public Health. 2018;18(1):410. https://dx.doi.org/10.1186\%2Fs12889-018-5298-8

17. Castillo M, Gutierrez R, Petrozzi V, Monsanto H, Rampakakis E, Altland A, Wolfson LJ. Carga económica de la varicela en niños en Perú, 2011-2016 [Economic burden of varicella in children in Peru from 2011 to 2016]. Rev Med Hered. 2019;30(2):76-86. http:// dx.doi.org/https://doi.org/10.20453/rmh.v30i2.3546

18. Meszner Z, Molnar Z, Rampakakis E, Yang HK, Kuter BJ, Wolfson LJ. Economic burden of varicella in children 1-12 years of age in Hungary, 2011-2015. BMC infectious diseases. 2017;17(1):495. https://doi.org/10.1186/s12879-017-2575-6

19. MedDRA, version 21.0 [Internet]. International Council for Harmonisation of Technical Requirements for Pharmaceuticals for Human Use (ICH); 2018 (https://www.meddra.org/, accessed 17 June 2020).

20. Jordan Food and Drug Administration [Internet]. [Medicine and price information]. [In Arabic] (http://www.jfda.jo/Pages/viewpage.aspx?pageID=184, accessed 21 December 2018.

21. [List of medical wages]. [In Arabic]. Amman: Jordan Medical Association; 2008 (http://www.jma.org.jo/Files/Medical-wages.pdf, accessed 21 December 2018.

22. Shepard D, Halasa-Rappel Y, Al-Halaseh I, Fardous T, Jrasat M, Abu-Shaer M. Health care cost study at Ministry of Health and the cost and financial impact of expanding the civil insurance program to vulnerable Jordanians and Syrian refugees. Amman: United Nations Children's Fund; 2017.

23. Hammad EA, Fardous T, Abbadi I. Costs of hospital services in Jordan. Int J Health Plann Manage. 2017;32(4):388-99. https://doi. org/10.1002/hpm.2343

24. Development of inflation rates in Jordan. World Data.info; 2018 [Internet] (https://www.worlddata.info/asia/jordan/inflation-rates.php, accessed 21 December 2018).

25. Cost of living in Jordan. Numbeo [Internet] (https://www.numbeo.com/cost-of-living/country_result.jsp?country=Jordan, accessed 21 December 2018).

26. Ginsberg GM, Somekh E. Cost containment analysis of childhood vaccination against varicella in Israel. J Infect. 2004;48(2):11933. https://doi.org/10.1016/s0163-4453(03)00079-3

27. Law B, Fitzsimon C, Ford-Jones L, MacDonald N, Dery P, Vaudry W, et al. Cost of chickenpox in Canada: part I. Cost of uncomplicated cases. Pediatrics. 1999;104(1 Pt 1):1-6. https://doi.org/10.1542/peds.104.1.1

28. XE currency converter. XE [Internet] (https://www.xe.com/currencyconverter/, accessed 21 December 2018).

29. Almuneef M, Memish ZA, Balkhy HH, Alotaibi B, Helmy M. Chickenpox complications in Saudi Arabia: is it time for routine varicella vaccination? Int J Infect Dis. 2006;10(2):156-61. https://doi.org/10.1016/j.ijid.2005.02.008

30. Uduman SA, Sheek-Hussein M, Bakir M, Trad O, Al-Hussani M, Uduman J, et al. Pattern of varicella and associated complications in children in United Arab Emirates: 5-year descriptive study. East Mediterr Health J. 2009;15(4):800-6.

31. Bonanni P, Breuer J, Gershon A, Gershon M, Hryniewicz W, Papaevangelou V, et al. Varicella vaccination in Europe - taking the practical approach. BMC Med. 2009;7:26. https://doi.org/10.1186/1741-7015-7-26

32. Nazer LH, Tuffaha H. Health care and pharmacy practice in Jordan. Can J Hosp Pharm. 2017;70(2):150-5. http://dx.doi. org/10.4212/cjhp.v70i2.1649

33. Almaaytah A, Mukattash TL, Hajaj J. Dispensing of non-prescribed antibiotics in Jordan. Patient Prefer Adherence. 2015;9:138995. https://doi.org/10.2147/ppa.s91649

34. Jordan statistics [Internet]. World Health Organization; 2014 (https://www.who.int/countries/jor/en/, accessed 21 December 2018). 